\title{
Synthesis of Nanostructured Catalytic Materials from Microemulsions
}

\author{
Margarita Sanchez-Dominguez ${ }^{1, *}$ and Magali Boutonnet ${ }^{2}$ \\ Received: 18 December 2015; Accepted: 22 December 2015; Published: 25 December 2015 \\ 1 Centro de Investigación en Materiales Avanzados, S. C. (CIMAV, Unidad Monterrey), GENES-Group of \\ Embedded Nanomaterials for Energy Scavenging, Apodaca 66600, Mexico \\ 2 KTH-Royal Institute of Technology, School of Chemical Science and Engineering, Department of Chemical \\ Engineering and Technology, Stockholm 10044, Sweden; magali@ket.kth.se \\ * Correspondence: margarita.sanchez@cimav.edu.mx; Tel.: +52-811-156-0830; Fax: +52-811-156-0820
}

\section{Background}

Since the 1980s [1,2], colloidal systems such as microemulsions (ME) have been widely investigated, especially for the synthesis of nanomaterials for various applications. In the field of catalysis, nanoparticles of noble metal or metal oxides, responsible for the catalytic activity and selectivity, are usually involved in the composition of the catalytic material [3]. A catalyst normally consists of metal nanoparticles deposited onto a carrier such as silica or alumina. Ideally, the nanoparticles will present a highly active surface area due to high metal dispersion. In addition, the surface structure of the nanoparticles, which depends on their size and shape, are related to the selectivity of the catalysts, for instance this is important in the case of alkane isomerization, which is a structure sensitive reaction [4].

Depending of the size, the nanoparticles will contain various defects, which will correspond to catalytic sites with different selectivities and activities. These active sites correspond to groups of metal atoms placed on the edges, corners, and terraces structures at the surfaces of the metal nanoparticles. These metal atoms will have different coordination states and present different electronic effects, which will consequently result in different catalytic activity and selectivity.

This is the reason why the preparation of nanoparticles with well-defined particle size is still of great interest in the field of catalysis. If one is able to obtain well-defined metal nanoparticles, it will be possible to relate the selectivity and activity of the reaction to some specific size and consequently to have a better understanding of the catalytic reaction mechanism. Consequently, by using a well-designed nanomaterial as catalyst, it will be possible to predict its properties regarding its catalytic activity and selectivity.

During these last years, it has been shown that nanomaterials obtained from ME present specific properties, especially regarding the catalytic selectivity compared to catalysts prepared from traditional methods. Several catalytic processes have been investigated using these types of catalysts, i.e., high temperature catalytic combustion of methane, electro-catalyst for hydrogen production from methanol, production of polyalcohols from synthesis gas, Diesel production from synthesis gas via Fisher-Tropsch and hydrocracking of waxes, etc. [3-11]. These very different processes are associated to a great range of catalytic materials. The microemulsion method, based on water-in-oil, oil-in-water and bicontinuous $\mathrm{ME}$, has shown to be suitable for the preparation of all these different types of materials [12-22].

Even though a few valuable efforts were previously done to understand the formation of nanomaterials in ME systems [23-25], comprehensive research in this area is still needed to clarify this process, in order to reach a better control of nanoparticle characteristics and to understand why the formed nanoparticles present specific catalytic properties compared to the materials with the same composition but prepared by traditional methods. Especially advanced analytical tools for deep 
microemulsion and nanoparticle characterization, detailed kinetics and dynamics, as well as theoretical modeling in conjunction with experimental results from systematic studies should be developed, in order to fully understand the formation and the structures of theses novel particles.

\section{The Present Issue}

First, the editors Margarita Sanchez-Dominguez and Magali Boutonnet would like to thank Keith Hohn, Editor-in-Chief for giving us the opportunity to organize this special issue and specially Mary Fan, Senior assistant editor for her constant support. We would like to thank the entire staff of the Catalysts Editorial office for their collaboration.

We would also like to thank all the authors who have contributed to this special issue reporting excellent and novel research work in one review and four articles.

The review article by Lopez-Quintela et al. [26] concerns the formation and properties of metallic clusters prepared from microemulsions. When Boutonnet $e t$ al. [1] showed that MEs offer a suitable environment for the preparation of Platinum nanoparticles, the size range obtained was in the order of 2-3 nm. However, one should think that clusters of metal atoms in the subnanometric scale are formed during the nucleation process, previous to these nanoparticles. Quintela et al. demonstrated for the first time that the microemulsion method based on AOT w/o microemulsion can be used for obtaining stable metallic clusters as final products. The interest in metal clusters is due to their specific properties such as very small size, specific geometry, quantum size effects (HOMO_LUMO gap), all these properties are of interest in various applications such as electro-catalysis, photocatalysis and bio-electro-catalysis.

Cobalt nanoparticles are the main components of Fischer-Tropsch catalysts for the production of biofuels such as gasoline and diesel from synthesis gas. The synthesis gas can be produced from gasification of biomass or wastes. The Fisher-Tropsch process is nowadays widely investigated due to the high demand of biofuels.

In their article [27], Di Carlo et al. reported the investigation of several preparation methods based on surfactant templates for the synthesis of Co nanoparticles with various particle size and shape. The methods were based on both $\mathrm{w} / \mathrm{o}$ and $\mathrm{o} / \mathrm{w}$ microemulsions, as well as micellar solutions of a triblock copolymer. Various sizes and shapes were obtained by using these different methods; the nature of the precipitating agent and the surfactant also played an important role. The $\mathrm{o} / \mathrm{w}$ microemulsion seems to be the most suitable method in order to obtain a uniform size distribution of Co nanoparticles. In this case, the Co particles were deposited onto silica support to obtain the final catalytic material. The characterization of this catalyst has shown that Co nanoparticles prepared in $\mathrm{o} / \mathrm{w}$ microemulsion remain well dispersed on the support, which makes this material appropriate as catalyst.

Bimetallic nanoparticles are of great interest in catalysis since new or improved catalytic properties can be obtained when adding a second metal. It has been shown that alloy metal nanoparticles can be obtained directly from bicontinuous microemulsions at low temperature whereas very high temperature is usually required when using conventional methods. This means that when using the ME method, the surface of the obtained alloys will not be affected by high temperatures giving rise to different properties comparing to bimetallic particles prepared by conventional methods at high temperatures.

By using the microemulsion method, not only bimetallic nanoparticles can be prepared but also core-shell bimetallic nanoparticles, as reported in the article by Westsson et al. [28]. Nanoparticles with a Ni core and a shell of Au were prepared and characterized by several techniques such as TEM, XRD, XPS, etc. From this study, it was concluded that, with the current synthesis techniques, it is not possible to completely control the geometrical properties of the core-shell nanoparticles. In addition, it was shown that currently, the analytical techniques that are available are not entirely appropriate for the characterization of such particles. According to the authors, one of the reasons that makes the characterization of core-shell bimetallic nanoparticles problematic is the presence of residual surfactant molecules on the surface of the nanoparticles. 
A synthesis procedure based on water-in-oil ME for mono $(\mathrm{Pt})$ and bimetallic $(\mathrm{PtBi}, \mathrm{PtPb})$ nanoparticles is reported in the article by König et al. [29]; furthermore, the catalytic activity was also reported [17]. As the authors concluded, bimetallic nanoparticles could be obtained, which consist of a mixture of different phases; the composition of the bimetallic particles was varied as a function of the metal salt ratio and the amount of reducing agent. Different catalytic tests were carried out: first, the electrochemical activity was tested using the electrochemical oxidation of formic acid. Since $\mathrm{CO}$ is formed during the reaction, some conclusion could be drawn concerning the resistance of the catalysts to $\mathrm{CO}$ poisoning. The $\mathrm{PtPb}$ electrode using the nanoparticles prepared in $\mathrm{ME}$ showed lower resistance towards $\mathrm{CO}$ compared to pure $\mathrm{PtPb}$ electrodes as well as similar activity. This difference in $\mathrm{CO}$ poisoning resistance could be associated to the presence of differences phases in the nanoparticles prepared using ME.

The same work reported the catalytic activity of the synthesized metallic nanoparticles deposited onto ethoxylated polyethylene amine in the reduction of 4-nitrophenol to 4-aminophenol. From this study, it was concluded that the Pt monometallic particles were more active then the bimetallic nanoparticles. The PtPb bimetallic nanoparticles present somewhat higher activity than PtBi bimetallic nanoparticles. Hydrogenation of allybenzene to propylbenzene was investigated as a third reaction using these nanoparticles deposited on alumina. All the catalysts were active in this reaction with a superior activity for the Pt nanoparticles. In this work, the potential of metallic $(\mathrm{Pt})$ and bimetallic ( $\mathrm{PtPb}$ and $\mathrm{PtBi}$ ) nanoparticles obtained from microemulsions was demonstrated for various catalytic applications.

The products of the Fisher Tropsch process included a mixture of biogas, low molecular hydrocarbons and waxes. It is quite difficult to obtain a catalyst that is very selective and that it will produce, for example, hydrocarbon molecules corresponding to the diesel or gasoline fractions. This is why one should aim to produce very high molecular weight molecules (waxes) and then crack them into diesel or gasoline fractions. Traditional hydrocracking catalysts used in refinery are based on Pt and zeolites. However, these catalysts cannot be employed for cracking of waxes since they will be highly efficient resulting in cracked products of very small molecular weight.

For this reason, new hydrocracking catalysts should be designed for this specific application. Regali et al. have used $0.2 \% \mathrm{Pt}$ on alumina as catalyst for this specific purpose [30]. This catalyst has shown to be efficient enough, presenting a selectivity to the diesel fraction up to $80 \%$, depending on the reaction conditions. In the work of Hanaoka et al. [31], a novel catalyst was obtained by immobilizing Pt nanoparticles (prepared in ME) onto zeolite. The effect of Pt particle size on the hydrocracking of FT waxes was investigated. The optimum jet fuel fraction obtained was $30 \%$ for a Pt particle size equal to $4.2 \mathrm{~nm}$. The microemulsion catalyst containing $0.11 \% \mathrm{Pt}$ on zeolite showed an improved catalytic activity compared with the catalyst prepared by traditional impregnation technique.

In summary, the articles published in this Special Issue demonstrate the feasibility of $\mathrm{w} / \mathrm{o}, \mathrm{o} / \mathrm{w}$ and bicontinuous microemulsions as confined reaction media for the synthesis of well-defined and highly active nanocatalysts, from simple metallic nanoparticles, to bimetallic alloy and core-shell nanoparticles, to subnanometer metallic clusters.

\section{References}

1. Boutonnet, M.; Kizling, J.; Stenius, P.; Maire, G. The preparation of monodisperse colloidal metal particles from microemulsions. Colloid Surf. 1982, 5, 209-225. [CrossRef]

2. Lindman, B.; Danielson, I. The definition of microemulsion. Colloid Surf. 1981, 3, 391-392.

3. Boutonnet, M.; Lögdberg, S.; Svensson, E.E. Recent developments in the application of nanoparticles prepared from w/o microemulsions in heterogeneous catalysis. Curr. Opin. Colloid Interface Sci. 2008, 13, 270-286. [CrossRef]

4. Amirebrahimi, V.; Garin, F.; Weisang, F.; Gault, F. Mechanism of skeletal isomerization of hydrocarbons on metals. New J. Chem. 1979, 3, 529-532. 
5. Agrell, J.; Boutonnet, M.; Melián-Cabrera, I.; Fierro, J.L. Production of hydrogen from methanol over binary $\mathrm{Cu} / \mathrm{ZnO}$ catalysts: Part I. Catalyst Preparation and Characterisation. Appl. Catal. A 2003, 253, 201-211. [CrossRef]

6. Agrell, J.; Boutonnet, M.; Fierro, J.L. Production of hydrogen from methanol over binary Cu/ZnO catalysts: Part II. Catalytic Activity and Reaction Pathways. Appl. Catal. A 2003, 253, 213-223. [CrossRef]

7. Anflo, K.; Agrell, J.; Ersson, A.; Järås, S.; Boutonnet, M.; Brandt, J.; Lyckfeldt, O. Sintering Resistant Catalyst material and a method for the preparation thereof. U.S. Patent 10/478,406, 23 October 2007.

8. Hernández-Fernández, P.; Rojas, S.; Ocón, P.; de la Fuente, J.L.G.; Terreros, P.; Pena, M.A.; García-Fierro, J.L. An opening route to the design of cathode materials for fuel cells based on PtCo nanoparticles. Appl. Catal. B 2007, 77, 19-28. [CrossRef]

9. Hanaoka, T.; Miyazawa, T.; Shimura, K.; Hirata, S. Jet fuel synthesis in hydrocracking of Fischer-Tropsch product over Pt-loaded zeolite catalysts prepared using microemulsions. Fuel Process. Technol. 2015, 129, 139-146. [CrossRef]

10. Li, H.; Liu, J.; Xie, S.; Qiao, M.; Dai, W.; Li, H. Highly active Co-B amorphous alloy catalyst with uniform nanoparticles prepared in oil-in-water microemulsion. J. Catal. 2008, 259, 104-110. [CrossRef]

11. Prieto, G.; Martínez, A.; Concepción, P.; Moreno-Tost, R. Cobalt particle size effects in Fischer-Tropsch synthesis: structural and in situ spectroscopic characterisation on reverse micelle-synthesised Co/ITQ-2 model catalysts. J. Catal. 2009, 266, 129-144. [CrossRef]

12. Suárez París, R.; Montes, V.; Boutonnet, M.; Järås, S. Higher alcohol synthesis over nickel-modified alkali-doped molybdenum sulfide catalysts prepared by conventional coprecipitation and coprecipitation in microemulsions. Catal. Today 2015, 258, 294-303. [CrossRef]

13. Zarur, A.J.; Hwu, H.H.; Ying, J.Y. Reverse microemulsion-mediated synthesis and structural evolution of barium hexaaluminate nanoparticles. Langmuir 2000, 16, 3042-3049. [CrossRef]

14. Aubery, C.; Solans, C.; Prevost, S.; Gradzielski, M.; Sanchez-Dominguez, M. Microemulsions as reaction media for the synthesis of mixed oxide nanoparticles: Relationships between Microemulsion Structure, Reactivity, and Nanoparticle Characteristics. Langmuir 2013, 29, 1779-1789. [CrossRef] [PubMed]

15. Aubery, C.; Solans, C.; Sanchez-Dominguez, M. Tuning high aqueous phase uptake in nonionic water-in-oil microemulsions for the synthesis of $\mathrm{Mn}-\mathrm{Zn}$ ferrite nanoparticles: Phase Behavior, Characterization, and Nanoparticle Synthesis. Langmuir 2011, 27, 14005-14013. [CrossRef] [PubMed]

16. de Oliveira, R.J.; Brown, P.; Correia, G.B.; Rogers, S.E.; Heenan, R.; Grillo, I.; Galembeck, A.; Eastoe, J. Photoreactive surfactants: A Facile and Clean Route to Oxide and Metal Nanoparticles in Reverse Micelles. Langmuir 2011, 27, 9277-9284. [CrossRef] [PubMed]

17. König, R.Y.G.; Stubenrauch, C. Pt Nanoparticles via Oil-in-Water Microemulsions Stabilized by a Technical Grade Surfactant: An Economical and Ecological Approach. Tenside Surfactant Deterg. 2015, 52, 106-112. [CrossRef]

18. Negro, E.; Latsuzbaia, R.; Koper, G.J. Bicontinuous microemulsions for high yield wet synthesis of ultrafine platinum nanoparticles: Effect of Precursors and Kinetic. Langmuir 2014, 30, 8300-8307. [CrossRef] [PubMed]

19. Sanchez-Dominguez, M.; Boutonnet, M.; Solans, C. A novel approach to metal and metal oxide nanoparticle synthesis: The Oil-in-water Microemulsion Reaction Method. J. Nanoparticle Res. 2009, 11, 1823-1829. [CrossRef]

20. Sanchez-Dominguez, M.; Koleilat, H.; Boutonnet, M.; Solans, C. Synthesis of Pt Nanoparticles in Oil-in-Water Microemulsions: Phase Behavior and Effect of Formulation Parameters on Nanoparticle Characteristics. J. Dispers. Sci. Technol. 2011, 32, 1765-1770. [CrossRef]

21. Sanchez-Dominguez, M.; Liotta, L.F.; Di Carlo, G.; Pantaleo, G.; Venezia, A.M.; Solans, C.; Boutonnet, M. Synthesis of $\mathrm{CeO}_{2}, \mathrm{ZrO}_{2}, \mathrm{Ce}_{0.5} \mathrm{Zr}_{0.5} \mathrm{O}_{2}$, and $\mathrm{TiO}_{2}$ nanoparticles by a novel oil-in-water microemulsion reaction method and their use as catalyst support for CO oxidation. Catal. Today 2010, 158, 35-43. [CrossRef]

22. Sanchez-Dominguez, M.; Pemartin, K.; Boutonnet, M. Preparation of inorganic nanoparticles in oil-in-water microemulsions: A Soft and Versatile Approach. Curr. Opin. Colloid Interface Sci. 2012, 17, 297-305. [CrossRef]

23. Lopez-Quintela, M.A. Synthesis of nanomaterials in microemulsions: Formation Mechanisms and Growth Control. Curr. Opin. Colloid Interface Sci. 2003, 8, 137-144. [CrossRef]

24. Destrée, C.; Nagy, J. Mechanism of formation of inorganic and organic nanoparticles from microemulsions. Adv. Colloid Interface Sci. 2006, 123, 353-367. 
25. Barroso, F.; Tojo, C. Modelling of nano-alloying and structural evolution of bimetallic core-shell nanoparticles obtained via the microemulsion route. J. Colloid Interface Sci. 2011, 363, 73-83. [CrossRef] [PubMed]

26. Buceta, D.; Piñeiro, Y.; Vázquez-Vázquez, C.; Rivas, J.; López-Quintela, M.A. Metallic clusters: Theoretical Background, Properties and Synthesis in Microemulsions. Catalysts 2014, 4, 356-374. [CrossRef]

27. Carlo, G.D.; Lualdi, M.; Venezia, A.M.; Boutonnet, M.; Sanchez-Dominguez, M. Design of cobalt nanoparticles with tailored structural and morphological properties via $\mathrm{O} / \mathrm{W}$ and $\mathrm{W} / \mathrm{O}$ microemulsions and their deposition onto Silica. Catalysts 2015, 5, 442-459. [CrossRef]

28. Westsson, E.; Koper, G.J. How to Determine the Core-Shell Nature in Bimetallic Catalyst Particles? Catalysts 2014, 4, 375-396. [CrossRef]

29. König, R.Y.; Schwarze, M.; Schomäcker, R.; Stubenrauch, C. Catalytic Activity of Mono- and Bi-Metallic Nanoparticles Synthesized via Microemulsions. Catalysts 2014, 4, 256-275. [CrossRef]

30. Regali, F.; Boutonnet, M.; Järås, S. Hydrocracking of n-hexadecane on noble metal/silica-alumina catalysts. Catal. Today 2013, 214, 12-18. [CrossRef]

31. Hanaoka, T.; Miyazawa, T.; Shimura, K.; Hirata, S. Preparation for Pt-Loaded zeolite catalysts using w/o microemulsion and their hydrocracking behaviors on Fischer-Tropsch product. Catalysts 2015, 5, 88-105. [CrossRef]

(C) 2015 by the authors; licensee MDPI, Basel, Switzerland. This article is an open access article distributed under the terms and conditions of the Creative Commons by Attribution (CC-BY) license (http://creativecommons.org/licenses/by/4.0/). 